\title{
The Value of micro-ELISA Test in the Diagnosis of Fasciola hepatica
} Infection

\author{
Fasciola hepatica Enfeksiyonunun Tanısında micro-ELISA Testinin Değeri
}

\author{
Muhsin Kaya', Remzi Beştaş ${ }^{1}$, Muttalip Çiçek², Akın Önder ${ }^{3}$, Mehmet Ali Kaplan \\ ${ }^{1}$ Department of Gastroenterology, Faculty of Medicine, Dicle University, Diyarbakır, Turkey \\ 2Department of Microbiology, Faculty of Medicine, Dicle University, Diyarbakır, Turkey \\ ${ }^{3}$ Department of General Surgery, Faculty of Medicine, Dicle University, Diyarbakır, Turkey \\ ${ }^{4}$ Department of Internal Medicine, Faculty of Medicine, Dicle University, Diyarbakır, Turkey
}

\begin{abstract}
Objective: In sero-diagnosis of parasitic infection, it is essential to inspect cross-reactivity between the target parasite and other parasites in order to assess diagnostic performance. The aim of this study was to determine the cut-off value of antibody titer for diagnosis of $F$. hepatica $(\mathrm{FH})$ infection by using the micro-ELISA and diagnostic performance of this test.

Methods: The study population consisted of the following groups: $F H$ group ( $n=42)$, Echinococcus granulosus (EG) group ( $n=27)$ and control group $(n=33)$. The micro-ELISA test for detection of anti- $F$. hepatica antibody was performed in all groups.

Results: The test was positive in all patients with $\mathrm{FH}$, in 3 out of $27(11 \%)$ patients with $\mathrm{EG}$ and in none of the control group. Mean antibody titer was significantly higher in the FH group compared to the EG group $(23.8 \pm 0.9 \mathrm{DU}$ vs. $5.7 \pm 1.2 \mathrm{DU} ; \mathrm{p}<0.001)$ and compared to the control group (23.8 $\pm 0.9 \mathrm{DU}$ vs. $2.4 \pm 0.2 \mathrm{DU} ; \mathrm{p}<0.001$ ). When we used $11,5 \mathrm{DU}$ as a cut-off value for sero-diagnosis of $\mathrm{FH}$, the positive predictive value was $93.3 \%$, negative predictive value was $100 \%$, sensitivity was $100 \%$, and specificity was $95 \%$.

Conclusion: Cross-reactions are an important issue in serological diagnosis of parasitic infections. The micro-ELISA test for FH antibody can not definitely discriminate fascioliasis from hydatid disease. (Turkiye Parazitol Derg 2013; 37: 23-7)
\end{abstract}

Key Words: Fasciola hepatica, Echinococcus granulosus, micro-ELISA test

Received: 14.09.2012

Accepted: 28.11 .2012

\section{ÖZET}

Amaç: Paraziter hastalıkların serolojik tanııında kullanılan testin güvenirliliğini saptayabilmek için, hedef parazit ile diğer parazitler arasındaki çapraz reaksiyonun göz önünde bulundurulması gerekir. Çalışmamızın amacı $F$. hepatica $(F H)$ tanısında kullanılan antikor titresinin eşik değerini saptamak ve testin güvenirliliğini ortaya koymaktır.

Yöntemler: Çalışmaya aşağıdaki gruplar alındı: FH grubu ( $n=42)$, Echinococcus granulosus (EG) grubu ( $n=27)$ ve kontrol grubu ( $n=33)$. FH antikorlarının saptanması için micro-ELISA testi tüm gruplarda çalışıldı.

Bulgular: Micro-ELISA testi FH grubundaki tüm hastalarda ve EG grubundaki 27 hastanın 3'ünde (\%11) pozitif saptanırken, kontrol grubundaki hiç bir hastada pozitif saptanmadı. Ortalama antikor titresi FH grubunda EG grubuna göre (23.8 \pm 0.9 DU vs. 5.7 $\pm 1.2 \mathrm{DU} ; \mathrm{p}<0.001)$ ve kontrol

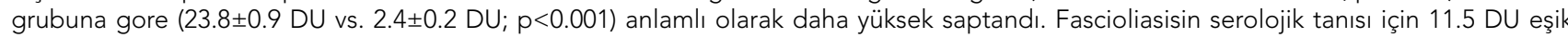
değer olarak alındığında, micro-ELISA testinin pozitif prediktif değeri \%93.3 ve negative prediktif değeri \%100; duyarlılığı \%100 ve özgüllüğü \%95 olarak saptandi.

Sonuç: Paraziter enfeksiyonlarda çapraz reaksiyon önemli bir sorundur. FH enfeksiyonunun serolojik tanısında kullanılan micro-ELISA testi fascioliasisi hydatik hastalıktan ayırmada tek başına yeterli bir yöntem değildir. (Turkiye Parazitol Derg 2013; 37: 23-7)

Anahtar Sözcükler: Fasciola hepatica, Echinococcus granulosus, micro-ELISA testi

Geliş Tarihi: 14.09.2012

Kabul Tarihi: 28.11.2012

Address for Correspondence / Yazışma Adresi: Dr. Muhsin Kaya, Department of Gastroenterology, Faculty of Medicine, Dicle University, Diyarbakir, Turkey Phone: +90 5323479458 E-mail: muhsinkaya20@hotmail.com doi:10.5152/tpd.2013.06 


\section{INTRODUCTION}

Fascioliasis is an infection caused by a trematode of the liver, F. hepatica, that particularly affects sheep, goats and cattle. The disease is transmitted to humans via ingestion of metacercaria from contaminated plants and after 3 to 4 months, the parasite is lodged in the biliary ducts of the liver. Afterwards, the final host releases the parasite eggs through the feces. Liver infection involves two stages- hepatic and biliary $(1,2)$. Common signs and symptoms of the hepatic phase are abdominal pain, fever, eosinophilia and abnormal liver function tests (1-4). The biliary phase usually presents with intermittent right upper quadrant pain with or without cholangitis or cholestasis $(4,5)$. Diagnosis may be delayed because of the wide spectrum of the differential diagnosis and low incidence of $F$. hepatica infection (1).

Diagnosis of $F$. hepatica infection has traditionally relied on detecting the presence of eggs in fecal samples, but this method is unreliable and complicated $(6,7)$. At present, the routine diagnosis of human fascioliasis is based on the detection of antifluke antibodies in serum. Methods such as immunoelectrophoresis and counterimmunoelectrophoresis, although they are very specific, have limited sensitivity $(1,8)$. Diagnosis was improved by the development enzyme-linked immunosorbant assay (ELISA) (9-11). The cross-reactivity between Echinococcus granulosus (EG) and $F$. hepatica infection has been reported previously (12-14). Parasitic helminths express some antigen which often accounts for serological cross-reactions. In serodiagnosis, it is essential to inspect cross-reactivity between the target parasite and other parasites in order to assess diagnostic performance (14).

The aim of this study was: to determine the cut-off value of antibody titer by using micro-ELISA for diagnosis of $F$. hepatica infection, to determine the positivity rate of micro-ELISA test for EG in patients with $F$. hepatica infection, to determine the diagnostic performance of micro-ELISA test for F. hepatica infection (1-3).

\section{METHODS}

\section{Study Population}

This prospective study was conducted in the department of Gastroenterology and General Surgery of Dicle University Hospital between February 2010 and April 2012. The study population consisted of the following groups: F. hepatica group, Hydatid disease group and control group. All patients gave written informed consent and the study was approved by the local Ethics Committee.

In all subjects, initial complete clinical history, physical examination findings, routine laboratory results including complete blood count and routine biochemical analysis were recorded. Contrast enhancement abdominal computerized tomographic (CT) examination was performed in all patients with $F$. hepatica infection and hydatid disease. Abdominal ultrasound (US) examination was performed in all patients in the control group. All the CT scans were obtained using a 4 channel multislice CT scanner (Sensation 4, Siemens Medical Solutions, Erlargen, Germany). A 3.75-MHz convex probe (Toshiba SSA-270 A, Tokyo, Japan) was used for US of the abdomen.
Micro-ELISA test using $F$. hepatica antigen from adult liver fluke [DRG Instrument GmbH, Germany; cut-off: 11.5 DRG Units (DU)] was used for serological diagnosis of fascioliasis. Titer of antibody was calculated according to the manufacturer's instruction.

The diagnosis of $F$. hepatica infection with the hepatic phase was based on: (a) The presence of previously described characteristic findings on the abdominal CT examination and exclusion of all known disease that cause hepatic lesions seen on CT examination; (b) and/or the presence of eggs of F. hepatica in the fecal examination $(3,4)$. The diagnosis of $F$. hepatica infection with the biliary phase was based on the extraction of living F. hepatica during endoscopic retrograde cholangio pancreaticography (ERCP).

The diagnosis of Hydatid disease was confirmed by characteristic CT findings before surgery and typical hydatid cystic appearance during surgery $(15,16)$.

Patients who were followed in the routine check-up department and without any disease were included in the study as the control group.

\section{Statistical Analysis}

Mean and standard deviation (SD) were calculated for continuous variables. The normality of the variables was analyzed by the Kolmogorov-Smirnov test. The Chi-square $\left(\chi^{2}\right)$ test was used for categorical variables. The one-way ANOVA test was used for normal distributed numerical values. The Kruskal-Wallis test was used for non-normal distributed numerical values. Two-sided $p$ values were considered statistically significant at $p \leq 0.05$. Analyses of nonparametric receiver operating characteristic (ROC) curves were performed to calculate the cut-off values. Statistical analyses were carried out by using the statistical packages for SPSS 17.0 for Windows (SPSS Inc., Chicago, IL, USA).

\section{RESULTS}

Table 1 shows demographic features and laboratory results of all groups. During the study period, 42 patients were diagnosed as F. hepatica infection. In all patients, the diagnosis of fascioliasis was based on positive micro-ELISA test (titers >11.5 DU) and characteristic abdominal CT findings. The mean titer of microELISA for F. hepatica 23.85 \pm 0.99 (range: 13-38) DU. Forty-one out of 42 patients were accepted as hepatic phase of fascioliasis. The remaining one patient was accepted as biliary phase of fascioliasis. The diagnosis of biliary phase of fascioliasis was confirmed by extraction of living mobile F. hepatica from extrahepatic biliary ducts during the ERCP procedure. Microscopic examination of fecal specimen for eggs of $F$. hepatica revealed positive results only in two out of 42 patients with the hepatic phase of fascioliasis. After confirmation of fascioliais, triclabendazole was administered at a dose of $10-12 \mathrm{mg} / \mathrm{kg}$ for 1 day in all patients. Six months after treatment, there was significant clinical, laboratory and tomographic improvement in all patients.

There were 27 patients in the hydatid disease group. Hydatid cyst was located with the right lobe of the liver in 18 patients, left lobe in 8 patients, and both lobes in 1 patient. The number of cysts was one in 18 patients, two in 6 patients and three in 3 patients. According to Gharbi's classification (16), there were type II cysts in 5 patients, type III in 15 patients and type IV in 7 
Table 1. Shows initial demographic and laboratory features of all groups

\begin{tabular}{|c|c|c|c|c|}
\hline & $\begin{array}{l}\text { Fasciola hepatica } \\
\text { group (F) }\end{array}$ & $\begin{array}{l}\text { Hydatid disease } \\
\text { group }(\mathrm{H})\end{array}$ & $\begin{array}{l}\text { Control } \\
\text { group (C) }\end{array}$ & $\begin{array}{c}\mathrm{p} \\
\text { value }\end{array}$ \\
\hline $\begin{array}{l}\text { Gender (M/F) } \\
\text { Age (range) }\end{array}$ & $\begin{array}{c}12 / 30 \\
41.9(18-72)\end{array}$ & $\begin{array}{c}9 / 18 \\
41.7(17-79)\end{array}$ & $\begin{array}{c}21 / 12 \\
31.4(15-65)\end{array}$ & $\begin{array}{c}\text { NS } \\
\text { F-H: } 0.726 \\
\text { H-C: } 0.043 \\
\text { F-C: } 0.001\end{array}$ \\
\hline $\begin{array}{l}\mathrm{Hb}(\mathrm{g} / \mathrm{dL}) \\
\mathrm{WBC}\left(\mathrm{n} / \mathrm{mm}^{3}\right)\end{array}$ & $\begin{array}{c}12.4 \pm 0.26 \\
10990 \pm 297\end{array}$ & $\begin{array}{c}12.5 \pm 0.3 \\
8420 \pm 552\end{array}$ & $\begin{array}{c}13.1 \pm 0.3 \\
6947 \pm 297\end{array}$ & $\begin{array}{c}\text { NS } \\
\text { F-H: } 0.028 \\
\text { H-C: } 0.05 \\
\text { F-C: } p<0.001\end{array}$ \\
\hline Eosinophil $\left(\mathrm{n} / \mathrm{mm}^{3}\right)$ & $3276 \pm 628$ & $406 \pm 189$ & $154 \pm 18$ & $\begin{array}{l}\text { F-H: }<0.001 \\
\text { H-C: } 0.103 \\
\text { F-C: }<0.001\end{array}$ \\
\hline $\mathrm{ALT}(\mathrm{U} / \mathrm{L})$ & $36 \pm 17$ & $60 \pm 28$ & $20 \pm 2.4$ & $\begin{array}{l}\text { F-H: }<0.001 \\
\text { H-C: } 0.011 \\
\text { F-C: } 0.001\end{array}$ \\
\hline AST (U/L) & $30 \pm 5.3$ & $43 \pm 13$ & $19 \pm 2.4$ & $\begin{array}{c}\text { F-H: } 0.267 \\
\text { H-C: }<0.003 \\
\text { F-C: } 0.031\end{array}$ \\
\hline GGT (U/L) & $64 \pm 13$ & $83 \pm 30$ & $27 \pm 4.6$ & $\begin{array}{c}\text { F-H: } 0.856 \\
\text { H-C: }<0.001 \\
\text { F-C: }<0.001\end{array}$ \\
\hline T. bilirubin (mg/dL) & $0.47 \pm 0.03$ & $0.9 \pm 0.18$ & $0.61 \pm 0.05$ & $\begin{array}{l}\text { F-H: } 0.039 \\
\text { H-C: } 0.898 \\
\text { F-C: } 0.039\end{array}$ \\
\hline ESR $(\mathrm{mm} / \mathrm{h})$ & $38 \pm 6$ & $12 \pm 1$ & $20 \pm 3$ & $\begin{array}{l}\text { F-H: }<0.001 \\
\text { H-C: } 0.258 \\
\text { F-C: } 0.014\end{array}$ \\
\hline Micro-ELISA (DU) & $23.8 \pm 0.9$ & $5.7 \pm 1.2$ & $2.4 \pm 0.2$ & $\begin{array}{l}\mathrm{F}-\mathrm{H}:<0.001 \\
\mathrm{H}-\mathrm{C}:<0.001 \\
\mathrm{~F}-\mathrm{C}:<0.001\end{array}$ \\
\hline
\end{tabular}

patients. The mean cyst diameter was $8.35 \pm 0.68$ (range: $34-122$ ) $\mathrm{mm}$. The mean titer of micro-ELISA for F. hepatica was 5.7 \pm 1.2 (range 1-32). The micro-ELISA test was positive in 3 out of 27 (11\%) patients. Of patients with positive anti- F. hepatica antibody, two patients were female, and all patients had one cyst located in the right lobe of liver.

There were 33 subjects in the control group. Abdominal US showed no mass lesion in any of the patients. The mean titer of micro-ELISA for F. hepatica was 2.4 0.25 (range: 1-6) DU. The micro-ELISA test was negative in all patients.

\section{Comparison of Groups}

The positivity rate of micro-ELISA was significanltly higher in the fascioliasis group compared to the hydatid disease group (100\% vs. $11 \% ; p<0.001)$ and compared to the control group $(100 \%$ vs. $0 \% ; p<0.001)$. Mean micro-ELISA titers were significantly higher in the fascioliasis group compared to the hydatid disease group (23.8 \pm 0.9 DU vs. 5.7 $\pm 1.2 \mathrm{DU} ; \mathrm{p}<0.001)$ and compared to the control group (23.8 $\pm 0.9 \mathrm{DU}$ vs. $2.4 \pm 0.2 \mathrm{DU} ; \mathrm{p}<0.001)$. When we used 11.5 DU as a cut-off value for sero-diagnosis of $F$. hepatica, the positive predictive value was $93.3 \%$, negative predictive value was $100 \%$, sensitivity was $100 \%$, specificity was $95 \%$.

There was no significant difference between the three groups regarding mean haemoglobin level. Mean eosinophil count was significantly elevated in the $F$. hepatica group compared to the hydatid disease group $(p<0.001)$ and the control group $(p<0.001)$. Serum alanine aminotransferase (ALT) level was significantly 
lower in the fascioliasis group compared to the hydatid disease group $(p<0.001)$ and significantly higher in the fascioliasis group compared to the control group $(p=0.001)$. There were no significant differences between the fascioliasis group and hydatid disease group regarding serum aspartate aminotransferase (AST) and gama glutamyl transferase (GGT) levels. Serum total bilirubin level was significantly higher in the fascioliasis group compared to the hydatid disease group and the control group $(p=0.039)$. Erythrocyte sedimentation rate was significantly higher in the fascioliasis group compared to the hydatid disease group $(p<0.001)$ and the control group $(p=0.014)$.

\section{DISCUSSION}

Parasitic helminths express various antigenic carbohydrates which often account for serological cross-reactions. In serodiagnosis, it is essential to inspect cross-reactivity between the target parasite and other parasites in order to assess diagnostic performance. Terminal Gal ( $\beta 1-6)$ Gal1-motifs have previously been shown to represent antigenic epitopes of neogala-series glycosphingolipids from tape worms (17). The Gal ( $\beta 1-6)$ Gal sequence is a common epitope between EG and $F$. hepatica (14). Wuhrer et al. (17) reported that $F$. hepatica exhibits mammalian-type glycolipids as well as Gal ( $\beta 1-6)$ Gal-terminating glycolipids that account for cestode serological cross-reactivity. Sera with $F$. hepatica infection have cross-reacted at the highest frequency (71.4\%) against Echinococcus multiloculari antigen. In patients with other parasitic infections, sera showed cross-reaction against $F$. hepatica antigen bound to Echinococcus multilocularis antigen with a high frequency (23.7\%) (14). In our previous study, we identified increased incidence of anti-Echinococcus granulosus antibody positivity using indirect immunofluorescence assay (IFA) in patients with F. hepatica infection (18). Şakru et al. (19) reported that 5 out of 226 (2,2\%) Echinococcus granulosus suspected cases were found seropositive for $F$. hepatica antibodies by an excretory secretory ELISA (ES-ELISA) test. In this study, we showed that micro-ELISA test for $F$. hepatica is positive in $11 \%$ of patients with EG infection and it is negative in healthy control. The commercial DRG test was evaluated in cattle, obtaining a sensitivity and specificity of $98 \%$ and $96 \%$ at a cut-off value of $15 \%$ positivity, respectively. The sensitivity and specificity of ELISA in-house assays using DRG test for $F$. hepatica IgG antibody have been reported as $92.6 \%$ to $100 \%$ and $83.6 \%$ to $100 \%$ respectively (20-22). This IgG antibody may be in as $32 \mathrm{DU}$ at high titers. The sensitivity of micro-ELISA test in our study is $100 \%$, but the specificity is significantly lower (50\%) compared to a previously reported study. Therefore, our findings are partially compatible with previously reported results. The false positive results of micro-ELISA test for F. hepatica in patients with hydatid disease may be related to antigenic similarity between F. hepatica and EG. The presence of cross-reactivity between parasites can suggest that serological tests without additional confirmative tests such as characteristic radiological findings are not reliable methods for diagnosis of these infections.

Typical organ lesion(s) detected by imaging technique (e.g. ultrasonography, computed tomography), specific serum antibodies assessed by high-sensitivity serological tests, histopathology or parasitology compatible with EG and detection of pathognomonic macroscopic morphology of cyst(s) in surgical specimens, confirm the diagnosis of EG (16). Routine laboratory tests are not specific for diagnosis of Hydatid disease and may reveal normal or abnormal values. Screening tests such as indirect hemagglutination, enzyme-linked immunosorbent assay (ELISA) and latex agglutination use crude antigens and are associated with a high incidence of false-negative and false-positive results. The parasitic antigens of major diagnostic value are antigen 5 (arc-5) and antigen $B$ (15). Purified fractions enriched in antigens 5 and $B$ and glycoproteins from hydatid fluid yielded a sensitivity rate of $95 \%$, with a specificity rate of $100 \%$ (23). The diagnosis of Hydatid disease was confirmed in all our patients by positive IFA test, computed tomography findings and pathognomonic surgical findings.

Diagnosis of fascioliasis may be delayed because of the wide spectrum of the differential diagnosis and low incidence of $F$. hepatica infection (3). Similar abnormal laboratory and radiological findings may represent viral hepatitis, liver abscess, malignancy, cholecystitis, sclerosan cholangitis, and AIDSrelated cholangitis, ruptured hydatic cyst and parasites such as ascariasis and clonorchiasis $(1,3)$. The sensitivity and specificity of ELISA in-house assays using the DRG test for F. hepatica IgG antibody are between $92.6 \%$ to $100 \%$ and $83.6 \%$ to $100 \%$; respectively (20-22).

Diagnosis is confirmed only by demonstrating the parasites or its egg in the bile or feces $(1,3)$. Negative stool examinations do not rule out the disease (3). A high index of suspicion and specific radiological findings including tunnel-like tracts extending towards the capsule and multiple, hypodense, linear or branching lesions on CT are very helpful in the diagnosis of fascioliasis (4). We suspected the possibility of fascioliasis in all patients with hepatic phase because of eosinophilia and characteristic CT findings. We found eggs in stool samples of two out of 42 (4.7\%) patients with hepatic phase. Complete clinical, laboratory and radiological response after triclabendazole administration, associated with positive result in high titer of micro-ELISA against $F$. hepatica, confirmed the diagnosis in patients with hepatic phase of $F$. hepatica infection. Diagnosis in the patients with biliary phase was confirmed by extraction of living F. hepatica form bile ducts. We can suggest that stool examination for eggs is not a reliable method and both serological test and extraction of living parasites from the bile ducts are very reliable methods for diagnosis of fascioliasis.

\section{CONCLUSION}

Cross-reactions are an important issue in serological diagnosis of parasitic infections. The micro-ELISA test for F. hepatica IgG antibody is positive in a minority of patients with hydatid disease and negative in healthy people. In clinical practice, the microELISA test for F. hepatica IgG antibody cannot reliably discriminate fascioliasis from hydatid disease

\section{Conflict of Interest}

No conflict of interest was declared by the authors.

\section{REFERENCES}

1. Lim JH, Mairiang $E, A h n$ GH. Biliary parasitic diseases including clonorchiasis, opisthorchiasis and fascioliasis. Abdom Imaging 2008; 33: 157-65. [CrossRef] 
2. Koç Z, Ulusan S, Tokmak N. Hepatobiliary fascioliasis: imaging characteristics with a new finding. Diagn Interv Radiol 2009; 15: 247-51.

3. Kabaalioğlu A, Çubuk M, Şenol U, Cevikol C, Karaali K, Apaydin A, et al. Fascioliasis: US, CT; and MRI findings with new observations. Abdom Imaging 2000; 25: 400-4. [CrossRef]

4. Kaya M, Beştaş R, Çetin S. Clinical presentation and management of Fasciola hepatica infection: single-center experience. World $\mathrm{J}$ Gastroenterol 2011; 17: 4899-904. [CrossRef]

5. Bektaş M, Dökmeci A, Çınar K, Halici I, Oztas E, Karayalcin S, et al. Endoscopic management of biliary parasitic diseases. Dig Dis Sci 2010; 55: 1472-8. [CrossRef]

6. Chen MG, Mott KE. Progress in morbidity due to Fasciola hepatica infection. Trop Dis Bull 1990; 87: 1-37.

7. Levine DM, Hillyer GV, Flores SI. Comparison of counterelectrophoresis, the enzyme-linked immunosorbent assay and Kato faecal examination for the diagnosis of fascioliasis in infected mice and rabbits. Am J Trop Med Hyg 1980; 29: 602-8.

8. Hillyer GV, Capron A. Immunodiagnosis of human fascioliasis by counterimmunoelectrophoresis. J Parasitol 1976; 62: 1011-3. [CrossRef]

9. Carnevale S, Rodríguez MI, Santillán G, Labbé JH, Cabrera MG, Bellegarde EJ, et al. Immunodiagnosis of human fascioliasis by an enzyme-linked immunosorbent assay (ELISA) and a micro-ELISA. Clin Diagn Lab Immunol 2001; 8: 174-7.

10. Rahimi MT, Ashra K, Koosha S, Abdi J, Rokni MB. Evaluation of FastELISA versus Standard-ELISA to Diagnose Human Fasciolosis. Arch Iran Med 2011; 14: 18-21.

11. Arias MS, Piñeiro P, Hillyer GV, Francisco I, Cazapal-Monteiro CF, Suárez JL, et al. Enzyme-linked immunosorbent assays for the detection of equine antibodies specific to a recombinant Fasciola hepatica surface antigen in an endemic area. Parasitol Res 2012; 110: 1001-7. [CrossRef]

12. Das K, Sakuja P, Aggarwal A, Puri AS, Tatke M. Non-resolving liver abscess with Echinococcosus cross-reactivity in a non-endemic region. Ind J Gasroenterol 2007; 26: 92-3.

13. Ramzy RM, Helmy H, El Zeyyat EA, Rifaat MM, Abdel Hameed DM, Abdel-Baki MH. An enzyme-linked immunosorbent assay for detection of lgG1 antibodies specific to human cystic echinococcosis in Egypt. Trop Med Int Health 1999; 4: 616-20. [CrossRef]

14. Yamano K, Goto A, Nakamura-Uchiyama F, Nawa Y, Hada N, Takeda T. GalB1-6Gal, antigenic epitope which accounts for serological cross-reaction in diagnosis of Echinococcus multilocularis infection. Parasite Immunol 2009; 31: 481-7. [CrossRef]

15. Sayek I, Tirnaksız MB, Dogan R. Cystic hydatid disease: Current trend in diagnosis. Surg Today 2004; 34: 987-96. [CrossRef]

16. Brunetti E, Kern P, Vuitton DA. Writing Panel for the WHO-IWGE. Expert consensus for the diagnosis and treatment of cystic and alveolar echinococcosis in humans. Acta Tropica 2010; 114: 1-16. [CrossRef]

17. Wuhrer M, Grimm C, Dennis RD, Idris MA, Geyer R. The parasitic trematode Fasciola hepatica exhibits mammalian-type glycolipids as well as Gal (B1-6) Gal-terminating glycolipids that account for cestode serological cross-reactivity. Glycobiology 2004; 14: 115-26. [CrossRef]

18. Kaya M, Beştaş R, Gırgın S, Çıçek M, Kaplan MA. Increased antiEchinococcus granulosus antibody positivity in Fasciola hepatica infection. Turk J Gastroenterol 2012; 23: 339-43.

19. Şakru N, Korkmaz M, Demirci M, Kuman A, Ok ÜZ. Fasciola hepatica Infection in Echinococcosis Suspected Cases. Turkiye Parazitol Derg 2011; 35: 77-80. [CrossRef]

20. Rokni MB, Massoud J, O'Neill SM, Parkinson M, Dalton JP. Diagnosis of human fasciolosis in the Gilan province of Northern Iran: application of cathepsin L-ELISA. Diagn Microbiol Infect Dis 2002; 44: 175-9. [CrossRef]

21. Espinoza JR, Maco V, Marcos L, Saez S, Neyra V, Terashima A, et al. Evaluation of Fas2-ELISA for the serological detection of Fasciola hepatica infection in humans. Am J Trop Med Hyg 2007; 76: 977-82.

22. Figueroa-Santiago O, Delgado B, Espino AM. Fasciola hepatica saposin-like protein-2-based ELISA for the serodiagnosis of chronic human fascioliasis. Diagn Microbiol Infect Dis 2011; 70: 355-61. [CrossRef]

23. Sbihi $Y$, Janssen D, Osuna A. Serologic regognition of hydatid cysts antigens using different purification methods. Diagn Microbiol Infect Dis 1996; 24: 205-11. [CrossRef] 